\title{
STUDENCKIE KOŁO NAUKOWE HISTORYKÓW FUW W WILNIE
}

W dniach od 18 do 23 listopada 1996 r. Koło Naukowe Historyków FUW sekcji Mohylew przebywało w Wilnie. Pierwotnym celem naukowego wyjazdu miało być miasto Mohylew, które jest tematem naszej pracy badawczej. Nie dotarliśmy tam z powodu rozruchów politycznych, trwających w tym czasie na Białorusi. Ostatecznie wspólnie z opiekunem naszej grupy podjęliśmy decyzję o przeprowadzeniu tygodniowej kwerendy w archiwach stolicy Litwy. Mieliśmy nadzieję, że odnajdziemy ciekawe jednostki archiwalne poszerzające nasze wiadomości.

Od kilkunastu miesięcy pracujemy nad tematem: Dzieje miasta Mohylewa $w$ Wielkim Kięstwie Litewskim. Uznaliśmy, że Mohylew - dawne miasto Rzeczypospolitej - jest interesujące ze względu na zawiłe losy polityczne i wyznaniowe. W ramach tego zagadnienia zajmujemy się następującymi problemami: historia polityczna miasta, gospodarką, arcybiskupstwem mohylewskim, parafią rzymskokatolicką, klasztorami, ludnością prawosławną i unicką.

W wyjeździe do Wilna uczestniczyła siedmioosobowa grupa studentów IV roku wraz z opiekunem dr Józefem Maroszkiem i dyrektorem Instytutu Historii prof. Barbarą Stępniewską-Holzer.

$\mathrm{Na}$ miejscu prowadziliśmy pracę w trzech placówkach naukowo-badawczych, tj. w Bibliotece Akademii Nauk Litwy, Centralnym Archiwum Historycznym Litwy oraz Bibliotece Uniwersytetu Wileńskiego.

Kilkudniowe bardzo intensywne prace przyniosły, jak sądzimy, interesujące rezultaty. Natrafiliśmy na źródło pisane ręką mohylewianina: „Krótkie dawniejsze opisanie miasta Mohylewa" Trubnickiego ${ }^{1}$. Po lekturze powyższej pozycji odnieśliśmy wrażenie, iż autor dość subiektywnie zinterpretował historię miasta i bynajmniej nie poczuwał się do lojalności wobec Rzeczypospospolitej. Jednak nie przesądza to o wartości kroniki.

Ogólne opracowania dotyczące Mohylewa można podzielić ze względu na czas powstania na dwie kategorie:

1) pochodzące głównie z końca XIX wieku, jak np.: M. W. Fursowa, Istoriczeskij oczerk Mogilewskoj gubernii ${ }^{2}$;

2) powstałe w XX wieku w ZSRR, jak np.: W. I. Maleszkowa, Mogilew w XVI - seredzinie XVII $w$. 
Nawet pobieżna lektura wskazuje na wykorzystanie bogatej bazy źródłowej i wnikliwą analizę problemu. Jednak nie uniknięto pewnych zakłamań.

Z zakresu zagadnień gospodarczych dużo materiałów odnosi się do kwestii ekonomii mohylewskiej. W Bibliotece Uniwersyteckiej znajduje się „Regestr liczb mohylewskich" ${ }^{3} \mathrm{z}$ pierwszej połowy XVII w., a także kopia prawa dzierżawy tejże ekonomii dla Krzysztofa Radziwiłła na okres czterech lat ${ }^{4}$.

Liczne dokumenty odnoszą się do arcybiskupstwa mohylewskiego. Większość $\mathrm{z}$ nich przechowywana jest $\mathrm{w}$ Bibliotece Akademii Nauk. Z ciekawszych warto odnotować dekret nuncjusza papieskiego Jana Andrzeja Archettiego z 19 lutego 1783 r. ${ }^{5}$, wynoszący kościół mohylewski pod wezwaniem Wniebowzięcia N.M.P. na archikatedrę oraz ukaz cara Rosji z 1798 r. ${ }^{6}$, w którym porządkowano organizację Kościoła katolickiego w Rosji. W Bibliotece Akademii Nauk znajduje się także cała seria dokumentów dotyczących arcybiskupa Bohusza Siestrzeńcewicza ${ }^{7}$.

Cennych wiadomości do dziejów Mohylewa moga dostarczyć akta zakonów. Wspomnieć należy, że na terenie miasta miały swoją siedzibę liczne zakony, jak: bernardyni, jezuici, karmelici, trynitarze trzewiczkowi oraz mariawitki. Najwięcej informacji dotyczy zakonu bernardynów. Podstawę stanowią dokumenty z wizytacji tego klasztoru z lat 1817, 1819, 1822, 1838, znajdujące się w zbiorach Biblioteki Uniwersyteckiej ${ }^{8}$. W konsystorzu mohylewskim z lat 1814 i 1817 można odnaleźć ślady działalności bernardynów ${ }^{9}$. Księgi grodzkie Wilna dostarczają również wiadomości, np. odnośnie zakonu karmelitów ${ }^{10}$. Sa to głównie akta dotyczące spraw majątkowych.

Tygodniowa kwerenda zdaje się dowodzić, iż najsłabsza baza źródłowa dotyczy kwestii unitów na terenie Mohylewa. Oprócz paru dosyć tendencyjnych i subiektywnych wzmianek w kronice Trubnickiego ${ }^{11}$ nie znaleźliśmy praktycznie nic innego. Opracowania zaś systematycznie pomijają ten problem.

Praca Koła Historycznego w bibliotekach i archiwach Wilna miała przede wszystkim charakter kwerendy, a nie analizy poszczególnych dokumentów. Tak naprawdę to dopiero zapoznawaliśmy się $\mathrm{z}$ metodami pracy $\mathrm{w}$ archiwach $\mathrm{i}$ efekty naszego pobytu nie moga być imponujące. Powiększyliśmy jednak zasób informacji dotyczący historii Mohylewa. Z pewnością większe korzyści przyniosłaby praca w archiwach Białorusi, co jednak późną jesienią 1996 r. było niemożliwe.

\section{Izabela Kotowicz Matgorzata Sokót}

\section{PRZYPISY}

1. Biblioteka Akademii Nauk Litwy (dalej cyt.: BANL), Krótkie dawniejsze opisanie miasta Mohylewa. Z kroniki rękopisanej P. Trubnickiego, sygn. B 3-228, F 17-228.

2. BANL, M. W. Fursow, Istoriczeskij oczerk Mogilewskoj gubernii, 1882, sygn. 628245.

3. Biblioteka Uniwersytetu Wileńskiego (dalej cyt.: BUWil), Regestr liczb mohylewskich, rkp. 1966. 
4. Centralne Archiwum Historyczne Litwy (dalej cyt.: CAH), sygn. SA 51.

5. BANL, Papiezius Pijus VI J. A. Archetti tarpininkaujant irengia Mogyliove R-katoliku arkivyskupystę Katerinai II viešpataujavol dokumento nuorašas, sygn. F 12-733.

6. BANL, Ukaz cara Rosji z 1798 r., sygn. 43-27003.

7. BANL, Papiery ... arcybiskupa Siestrzeńcewicza... (Arcivyskupo Siestrzeńcevicius) 1757 -1817, sygn. F 43-13188; Regestr Papierów tyczących się Dóbr w possessyi Metropolity... Stanisława Siestrzeńcewicza Bohusza... 1816, sygn. F 43-13202; Rejestr Papierów pozostałych po S.p. Arcy-Biskupa Siestrzeńcewicza, 1823, sygn. F 43-13206.

8. BUWil., rok 1817, sygn. A-2109; rok 1819, sygn. A-2108; rok 1822, sygn. A-2116; rok 1838, sygn. A-2157.

9. BANL, sygn. F 43-13197, F 273-1743, F 273-1746, F 273-1744.

10. CAH, Księgi grodzkie Wilna, sygn. 4731 (kart. 173-174), 159 (kart. 244-245), 6108 (kart. 993-994).

11. Trubnicki, op. cit. 